\title{
International Organizations Policies and New Era of Work: Education in What Skills?
}

\author{
Zoe Karanikola (Corresponding Author) \\ Technological Educational Institution of Western Greece \\ Megalou Alexandrou 1, Patras, 26334, Greece \\ Tel: 69-49-973-053Ｅ-mail: zoekaranikola3@gmail.com
}

George Panagiotopoulos

Technological Educational Institution of Western Greece

Megalou Alexandrou 1, Patras, 26334, Greece

Tel: 69-72-663-858Ｅ-mail: gpanag65@gmail.com

Received: September 14, 2018 Accepted: November 14, 2018 Published: November 18, 2018

doi:10.5296/ijld.v8i4.13928ＵRL: https://doi.org/10.5296/ijld.v8i4.13928

\begin{abstract}
This paper comes to examine the intense reflection that arises around the issue of the right and the appropriate skills employees need to obtain in order to adapt to a continuously changing working environment. In a context of global co-operation and coalition, international organizations, such the Organization for Economic Cooperation and Development (OECD) and the European Union (EU) Institutions, are called upon to play an important role in the development of prosperity, social cohesion and the economy of the countries, given that they have both the appropriate experience and the extensive diplomatic networks. In such a context, a great number of significant official texts have been drafted. Texts which provide policy guidance to member states in order to achieve growth and development. This study, through the bibliographic review of related texts, comes to investigate the proposed by the international organizations types of skills which are related to the protection and the maintenance of employability.
\end{abstract}

Keywords: Skills, international organizations, OECD, European commission, UNESCO 


\section{Theoretical Underpinning}

\subsection{Introduction}

The 21 st century is the century where occupational survival depends on the quality of personal skills. Mastering a variety of skills can be a distinguishing mark of an individual in the era of competition, multiculturalism and globalization (Riaz, 2016). Though, according to the OECD Survey (2013) of employability skills, roughly one third of workers are over or under qualified for their job, while one sixth report a mismatch between their existing skills and those qualified for their job. Skill gaps, skill shortages and skill mismatches can affect labor productivity and employability.

Tackling these skills challenges will require significant policy efforts and systemic reforms in education and training of human capital from both public and private sources. In such a context, improving the quality and relevance of skills formation and making them more visible and comparable becomes a matter of major importance and a reference point for the policies of international organizations. Thus, the UN with the Sustainable Development Goals program, adopted in September 2015, establishes seventeen key objectives for sustainable development. As it is stated in the preamble of its official text, it is "an action plan for people, the planet and prosperity" (UN, 2015: 1). In addition, it aims to ensure equal access for all women and men to affordable and high-quality technical and vocational education, and calls on governments to equip adults with skills that will ensure decent work for everyone, increase productivity, promote their labor rights. In an effort to align with UN objectives, International Organizations, such as the OECD, the UNESCO and the European Commission, have drafted texts which aim, through the adoption of common cohesion and synergy policies, to help achieve the goals of delivering the right skills.

\subsection{Contemporary Context of Education and Development}

An African motto says that anyone who does not participate in learning is considered "oku eniyan", meaning "living dead", thus stressing the value and necessity of learning (Avoseh, 2001: 483). This is not a coincidence since education is the largest source of culture but also accepts all social changes (Schumacher, 1980). Most of the Western societies are characterized by heterogeneity in the composition of their population, mainly due to immigration. It is estimated that at the beginning of the 21 st century, more than 150.000 .000 people on the planet live in different countries than those born. This is due to the great development differences between countries in terms of their economic and social development, the rapid increase in the world population since the beginning of the 19th century, the major changes that took place in the world map after the Second World War, the revolutionary technological developments in transport and telecommunications, and globalization (Kontis \& Fakiolas, 2002).

In particular, the term globalization refers to the movement of goods, services, people, ideas outside national borders and it is widely used. Movement is a perpetual feature of human societies, but what changes today is the intensity and speed at which it is achieved. Friedman, referring to the phenomenon of globalization, argues that we have passed from "connecting" to "hyperconnecting", while Cowen believes that the whole world has become a big shopping 
mall (Merriam \& Bierema, 2014: 2).

But education itself has also become a commercial market. Friedman (2005) in his book "The World is a Flat: A Short History of the Twenty-First Century" provides several examples of global commercialization of education. There are parents in the USA who hire Indian teachers to teach their children math and science through internet at the lowest cost, while at the same time the academic community is evolving into a revenue-buying and selling business, so on the one hand students buy education and on the another hand colleges and universities are buying students.

Another special feature of our era is the rapid increase in knowledge, which is linked to or is called to be linked to the labor market and the economy. Educational systems, in a context of sustainability and social development, have to provide knowledge and skills that will make future employees capable of searching and finding a job, and those already in work capable of retaining their jobs, changing it or even developing it. Though, not only companies move there where they can find a skilled workforce but also workers themselves often leave their homeland to go somewhere where their mindset and skillset can be used. Spring (2008) considers that brain drain has now passed into the brain circulation phenomenon, as proficient and worthy professionals move among wealthy nations in order to provide their skills.

In addition, the knowledge society becomes very strong and has replaced the industrial society. In addition, it is more demanding and complex than the information society. Information has to be organized and structured in order in order to gain value and importance. How easy, however, and feasible is this given that the information is doubled every two years while web information every 90 days? (Merriam \& Bierema, 2014: 4-5).

In addition, we are at the beginning of a new technological revolution, the fourth, which undoubtedly affects all areas of human life, bringing about rapid changes in people's way of living, working, communicating and interacting. Billions of people are linked to mobile phones, the potential of which is unimaginable: unprecedented processing power, storage capacity, access to knowledge. What is more robotics, the Internet of Things, autonomous vehicles, artificial intelligence, 3-D printing, biotechnology, energy storage, nanotechnology cause enormous possibilities. In addition, transport and communication costs will drop, new ecosystems will develop, citizens will be empowered by using technology (Karanikola \& Panagiotopoulos, 2018; Schwab, 2015).

All these changes bring about rapid changes in the workplace. In such a context people need to redefine their skills and mindset in order to be able to handle all these changes and become employable (Boaden, 1997, Dearing 1997; Hillage and Pollard, 1999).

\subsection{Skillset and International Organizations}

Employability is a complex and lifelong process and refers to the capacity of getting and keeping satisfactory and fulfilling work. It is also considered to be a product of skillful career planning and interview technique, a mix of cognitive and non -cognitive achievements and representations (Knight \& Yorke, 2005). According to Dearing (1997), it is linked to the acquisition of skills, while Hillage and Pollard (1999) suggest that it should also be considered 
in terms of knowledge and attitudes. Consequently, one major factor that helps people be employable is skills. Skills refer to a set of achievements, understanding, knowledge and personal attributes that make individuals more likely to get employed and be successful in their chosen occupations. Right skills ensure that labor market participants have the capability of being effective in their workplace - to the benefit of themselves, their employer and the wider economy (Knight \& Yorke, 2004).

The need to develop skills and connect them with the development of the worker is a lasting historical challenge and also reflected in the drafting of many texts by international and European organizations (UN, UNESCO, OECD, European Commission). In this historical challenge, the UN plays a special role through its policies and programs. The Universal Declaration of Human Rights has been the basis for many others, including the Millennium Development Goals Program (2000-2015) and the "Agenda 2030 - Sustainable Development Goals" (2015-2030). The goal of the Agenda is to engage all the developing and non-developing countries and its basic promise is: "No one will be left behind" (UN, 2015: 3). It includes 17 global, ambitious, linked objectives and 169 goals which aim to eradicate poverty and hunger, generalize the education at all levels both in developing and developed countries, develop gender equality, health, well-being and prosperity, improve access to new forms of energy, environmental protection and respect for human rights.

In addition, the Organization for Economic Co-operation and Development (OECD) provides a forum in which countries can collaborate and find solutions to common universal problems. Its mission is to measure productivity and global flows of trade and investment, to predict future trends, to re-establish healthy finances, to support new sources of growth through innovation and to ensure that people of all ages can develop the skills to work productively and satisfyingly in the jobs of tomorrow (Panagiotopoulos \& Karanikola, 2018). Jobs of tomorrow bring about stress and uncertainty, given that technological and digital developments provoke rapid changes in production systems, administration, management and employment. Though "education can make the difference whether people embrace the challenges they are confronted with or whether they are defeated by them. What is more, education has a vital role to play in developing knowledge, skills, attitudes and values that enable people to contribute to and benefit from an inclusive and sustainable future. Learning to form clear and purposeful goals, working with others with different perspectives, finding untapped opportunities and identifying multiple solutions to big problems will be essential in coming years. Education needs to aim to do more than prepare young people for the world of work; it needs to equip students with the skills they need to become active, responsible and engaged citizens" (OECD, 2018: 3-4).

Regarding the European Union, it has a long history in shaping policies regarding the development and prosperity of societies. Thus, at the beginning of the 1990s, the European Community stressed the importance of coherence in the effectiveness of development policies, while the Treaty of Lisbon (2009) states that the Union should take into account the fact that the coherence and cooperation of policies can affect developing countries (Mackie, 2007).

Last but not least, UNESCO, within a framework of global cooperation for the well-being and 
development of people and societies, has taken the necessary steps. It prepares official texts, based on international research data, analyzes policies, develops mechanisms for evaluating programs and actions (European Commission, 2016).

\section{Presentation of Research Material}

This study, through the bibliographic review of three texts, comes to reflect the types of skills which are advanced and proposed by the international organizations. The texts which were studied are: the OECD text, "OECD Skills outlook 2017: Skills and global value chains", the European Commission text "Communication: A new skills agenda for Europe" and the UNESCO text "Third World Report on Adult Learning and Adult Education" (GRALE III, 2016).

The first text is a product of a collaborative effort among several directorates in the OECD Secretariat (Directorate for Science, Technology and Innovation). The Skills Outlook puts emphasis on the fact that the heart of global value chains are people. People are those who conceive, design, produce, assemble and transport a product. People are the consumers of this product. However, whether they can participate in these processes or not, depends on their skills.

The new Skills Agenda for Europe was adopted by the Commission on 10 June 2016. It is the result of communication from the Commission of the European Parliament, the Council, the European Economic and Social Committee and the Committee of the Regions. This agenda aims to make sure that European people develop the right skills for the jobs of today and tomorrow. This task is essential to boost employability, competitiveness and growth across the EU. Besides, it calls on EU countries and stakeholders to improve the quality of skills and their relevance for the labor market. Different actions are designed in order to improve the quality and relevance of training and other ways of acquiring skills, to make skills visible and to enable people make better career choices, find quality jobs and improve their life chances.

Finally, UNESCO's Third World Report on Adult Learning and Adult Education (GRALE III, 2016) addresses the implementation of the Belem framework of action, which was adopted by 144 UNESCO member states at the 6th International Conference on Learning and Adult Education Adult Education in Brazil in 2009. The findings of this report relate to the efforts of the global community to achieve the goals of Agenda 2030. This report, like the previous two, collects the latest developments concerning adult learning, underlines how good policies and practices encourage governments to undertake a process of evaluation and redefinition of their efforts (Panagiotopoulos \& Karanikola, 2017a).

\section{Bibliographic Review of Texts of International Organizations and Skills}

Regarding the type of skills which are proposed by the OECD, it is found that six skills domains are proposed: information and communications technologies skills, management and communication skills, self - organizing skills, marketing and accounting skills, science, technology, engineering and mathematics (STEM) skills, and readiness to learn. Information and Communication technologies (ICT) skills includes all the described tasks associated with ICT use, from reading and writing emails to using word-processing or spreadsheet software, or 
a programming language (OECD, 2017:79).

In addition, management and communication skills gather a more diverse set of items, from teaching people to planning activities. All these activities involve communicating and managing other people, whether they are co-workers or not. Self-organizational skills, like readiness to learn, refer to "Work flexibility - Speed of work" or "Work flexibility - Sequence of tasks". Marketing and accounting skills is a newly constructed indicator that does not correspond to any indicator in the normative typology. "Reading financial statements", "calculating costs or budgets" and "selling products or services" are associated with this factor, as well as "using a calculator". Although the last item also loads on "ICT contents" and "STEM contents" it seems that calculators are mainly used for marketing and accounting purposes (OECD, 2017:79). Regarding STEM skills, they have not been present in the normative typology. Like Marketing and Accounting Skills, it involves numeric tasks such as "Use Simple algebra or formulas" or "Use advanced math or statistics", but they are more complex and less specific than those loading on the previous factor. This factor is interpreted broadly as skills necessary for Science, Technology, Engineering and Mathematics (OECD, 2017:79). Readiness to learn consists exclusively of items designed in the Survey of Adult Skills to measure this dimension, e.g. "Relate new ideas into real life" or "Like learning new things" (OECD, 2017:79; Panagiotopoulos \& Karanikola, 2018).

Regarding the second text, "The new Skills Agenda for Europe", there are significant references to the basic skills, such as numeracy, literacy, basic digital skills and to more complex skills. Skills that open doors to personal fulfillment, development and prosperity, social inclusion, active citizenship and employment. Science and foreign languages are referred as some of them. Transversal skills, including entrepreneurship, critical thinking, problem solving, learning to learn, financial literacy, innovation and creativity, is another important category.

Regarding the third text, GRALE III, digital skills and the promotion of environments supporting digital economy, action and innovation are of the highest priority. Equally important are the practical and digital skills that increase people's potential for information and communication through the use of friendly and easily accessible technology tools (Zinnbauer, 2007; Organization for Economic Co-operation and Development, 2015). Another important category of skills, especially for vulnerable groups, is "life" skills that help adults become more flexible and able to solve problems and improve their quality of life (Jenkins, 2011; Organization for Economic Co-operation and Development, 2013).

Cultural learning and the development of skills in art, music and theatre are of major importance. These skills have a positive impact on the reformation and change of identity, the development of motivation, trust, empathy and social commitment (Innocent, 2010), and they also promote tolerance and social cohesion in culturally heterogeneous societies (Feksi, Mtey \& Sulle, 2013; Kil, Operti \& Manninen, 2012; Organization for Economic Co-operation and Development, 2007). Of great importance are also the "social capital" skills which help individuals become active participants in community and political life, broaden their general knowledge and maintain social connections (Bosche \& Brady, 2013; Field, 2005). Finally, 
economic skills contribute to the achievement of the aims of Agenda 2030 for sustainability and growth. These skills are also associated with ethics, which help employees develop their moral compass and thus fulfill their corporate and social responsibility (Hartman, 2013).

\section{Conclusion}

According to the bibliographic overview of all three texts, we can find out that many different skills predominate, meaning that specialized knowledge is not sufficient for the successful career of an employee. Emphasis is placed on the need to develop mixed skills. Cognitive skills partly reflect the ability to learn and help predict the occupational level of workers, while they influence individual earnings, the distribution of income and more generally economic growth (Hanushek \& Woessmann, 2008). Numeracy and mathematical skills, as well, are directly conducive to business success, particularly in technologically advanced industries (Hoyles et al., 2002) and make technological breakthroughs possible (OECD, 2017:76). Though, emotional and interpersonal skills complement all the other types of skills, while their lack can create a strong barrier to employment, especially for low skilled jobs (Heckman \& Kautz, 2013). The building of these skills can contribute to the development of self-confidence, self-fulfillment and personal efficiency and performance (Schuller et al., 2006). Through these skills, people can take on new challenges and provide practical and emotional support to those around them (Balatti et al., 2007).

It is also noted that there is a strong demand for the right skills, given that under-employment and unemployment are now affecting the lives of more and more people worldwide. Many people are either inactive or working somewhere below their level of skills and abilities. In addition, the nature of work and employment contracts are constantly changing and people feel more and more insecure and vulnerable (Panagiotopoulos \& Karanikola, 2017b).

\section{Implication for Research and Practice}

The importance of this study lies in the fact that it provides useful contemporary information on the international organizations' efforts to meet the contemporary demands of employment and employability, thus creating large databases. Data that will multiply and will be indicators of evaluation and comparison of relevant actions at a local, national or international level. Skills can be a pathway to employability and prosperity, a key to social cohesion, a pull factor for investment. However, in a future research, it would be useful to explore what will actually take place and how it will be implemented. Current and future skills need to vary across different sectors of the economy. Universities and VET need to understand labour market trends. Work-based learning and apprenticeships are a proven springboard to developing labour relevant skills, including transversal and soft skills. The cooperation of International Institutions and Organizations will contribute to the delivery of these skills.

\section{References}

Avoseh, M. B. M. (2001: 483). Learning to be Active Citizens: Lessons of traditional Africa for lifelong learning. International Journal of Lifelong Education, 20(6), 479-486. https://doi.org/10.1080/02601370110088454 


\section{Macrothink}

International Journal of Learning and Development

ISSN 2164-4063 2018, Vol. 8, No. 4

Balatti, J., Black, S. \& Falk, I. (2007). Teaching for social capital outcomes: The case of adult literacy and numeracy courses. Australian Journal of Adult Learning, 47(2), 245-63.

Bosche, B. \& Brady, B. (2013). Benefits des community learning: Ergebnisse aus Irland, in Benefits of lifelong learning. DIE Journal for Adult Education, 1, 30-34.

Dearing, R. (1997). Higher Education in the Learning Society. Report of the National Committee of Enquiry into Higher Education. London: HMSO.

European Commission. (2016). Next steps for a sustainable European future: European action for sustainability. Strasbourg.

Feksi Mtey, K., \& Sulle, A. (2013). The role of education in poverty reduction in Tanzania. Journal of Educational Research and Review, 2(1), 6-14.

Field, J. (2005). Social Capital and Lifelong Learning. Bristol: Policy Press.

Friedman, T. L. (2005). The World is a Flat: A Short History of the Twenty-First Century, Farrar. New York: Straus \& Giroux.

Hanushek, E. A., \& Woessmann, L. (2008). The role of cognitive skills in economic development. Journal of Economic Literature, 46(3), 607-668. https://doi.org/10.1257/jel.46.3.607

Heckman, J. J., \& Kautz, T. (2013). Fostering and measuring skills: Interventions that improve character and cognition, NBER Working Paper, No. 19656. Cambridge MA: The National Bureau of Economic Research.

Hillage, J. \& Pollard, E. (1998). Employability: developing a framework for policy analysis. Research Brief No. 85. London: Department for Education and Employment.

Hoyles, C. et al. (2002). Mathematical skills in the workplace: Final report to the Science Technology and Mathematics Council. London: Institute of Education.

Innocent, N. (2010). Learning to Manage Change in the Third Age. Adults Learning, 21(10).

Jenkins, A. (2011). Participation in Learning and Well-being Among Older Adults. International Journal of Lifelong Education, 30(3), 403-420. https://doi.org/10.1080/02601370.2011.570876

Karanikola, Z. \& Panagiotopoulos, G. (2018). 4th Industrial Revolution: The Challenge of Changing Human Resources Skills. European Journal of Training and Development Studies, $5(3), 1-7$.

Kil, M., Operti, F., \& Manninen, J. (2012). Measuring benefits of lifelong learning. Lifelong Learning in Europe, 3, 4-5.

Knight, P., \& Yorke, M. (2005). Learning and Employability: Judging and communicating achievements. United kingdom: The Higher Education Academy. 
Knight, P., \& Yorke, M. (2004). Learning, Curriculum and Employability in Higher Education. London: Routledge Falmer.

Mackie J. (2007). Evaluation of the EU Institutions \& Member States' Mechanisms for Promoting Policy Coherence for Development, Study for the Evaluation Services of the Ministries of Foreign Affairs of France and Belgium, the Federal Ministry of Development Cooperation Germany and DG Europe Aid, European Commission, The Triple C Evaluations (7). Amsterdam: Aksant Academic Publishers. Retrieved from http://ecdpm.org/publications/evaluation-study-eu-member-states-mechanisms-pcd/

Merriam, S. B., \& Bierema, L. (2014). Adult Learning, Linking Theory and Practice. Jossey Bass.

Organisation for Economic Co-operation and Development. (2018). The future of education and skills. Education 2030, The future we want. Paris: OECD Indicators.

Organisation for Economic Co-operation and Development. (2017). OECD Skills outlook 2017: Skills and global value chains. Paris: OECD Publishing. https://doi.org/10.1787/9789264273351-en

Organisation for Economic Co-operation and Development. (2015). Health at a Glance 2015. Paris: OECD Indicators.

Organisation for Economic Co-operation and Development. (2013). Skills Outlook 2013: First Results from the Survey of Adult Skills. Paris: OECD Publishing.

Organisation for Economic Co-operation and Development. (2007). Understanding the social outcomes of learning. Paris: OECD Publishing.

Panagiotopoulos, G., \& Karanikola, Z. (2018). Occupational and Professional Development: OECD Policy Analysis on Skills. International Journal of Developing and Emerging Economies, 6(4), 1-10.

Panagiotopoulos, G., \& Karanikola, Z. (2017a). Labor Market and Development: UNESCO Research Data on Human Resource Training. European Journal of Training and Development Studies, 4(3), 62-72.

Panagiotopoulos, G., \& Karanikola, Z. (2017b). Skills a pathway to employability and prosperity: European Commission Policies. International Journal of Education, Learning and Development, 5(10), 92-101.

Riaz, M. (2016). The importance of skills. Published in The Express Tribune, 25/4/ 2016.

Schwab, K. (2015). The fourth industrial revolution. What it means and how to respond, Foreign Affairs. Retrieved from https://www.foreignaffairs.com/articles/2015-12-12/fourth-industrial-revolution

Schuler, R. S., \& Jackson, S. (2006). Human Resources Management: positioning for the 21st century. NY: West Publishing. 


\section{Macrothink}

International Journal of Learning and Development

ISSN 2164-4063 2018, Vol. 8, No. 4

Schumacher, E. (1980). The little one is beautiful. Athens: Glaros.

Spring, J. (2008). Research on globalization and education. Review of Educational Research, 78(2), 330-336. https://doi.org/10.3102/0034654308317846

United Nations General Assembly. (2015). Transforming our world: the 2030 Agenda for Sustainable Development, Resolution A/RES/70/1 of 25 September 2015.

United Nations General Assembly. (2000). United Nations Millennium Declaration, Resolution A/RES/55/2 of 8 September 2000.

UNESCO. (2016). 3rd World Report on Adult Learning and Adult Education, The Impact of Adult Learning and Education on Health and Well-Being; Employment and the Labor Market; and Social, Civic and Community Life, UNESCO Institute for Lifelong Learning, Hamburg.

UNESCO Institute for Lifelong Learning. (2013). Saakshar Bharat Mission, Effective Literacy and Numeracy Practices Database (LitBase). Hamburg: UNESCO Institute for Lifelong Learning. Retrieved from http://www.unesco.org/uil/litbase/?menu=9\&programme $=132$

UNESCO. (2015). Recommendation on Adult Learning and Education. Retrieved from http://www.unesdoc.unesco.org/images/0024/002451/245179e.pdf

UNESCO Global Monitoring Report. (2012). Investing in skills for prosperity. Education for all. Retrieved from http://www.unesco.org/fileadmin/.../gmr2012-report-ch4.pdf

Zinnbauer, D. (2007). What can Social Capital and ICT do for Inclusion? European Commission, Directorate-General Joint Research Centre, Institute for Prospective Technological Studies. Retrieved from http://ftp.jrc.es/EURdoc/eur22673en.pdf

\section{Copyright Disclaimer}

Copyright for this article is retained by the author(s), with first publication rights granted to the journal.

This is an open-access article distributed under the terms and conditions of the Creative Commons Attribution license (http://creativecommons.org/licenses/by/4.0/). 